\title{
Groundwater Sustainability and The Divergence of Rock Types in a Typical Crystalline Basement Complex Region, Southwestern Nigeria
}

\author{
Bawallah Musa ADESOLA ${ }^{1}{ }^{\circledR}$, Adiat Kola ABDUL-NAFIU1 ${ }^{\circledR}$, Akinlalu Ayokunle ADEWALE1 ${ }^{\circledR}$, Ilugbo Stephen \\ OLUBUSOLA $^{* 1}$, Akinluyi Francis OMOWONUOLA ${ }^{2}$, Benjamin Odey OMANG $^{3} \odot$, Oyedele Akintunde \\ AKINOLA $^{4}{ }^{\circledR}$, Omosuyi Oluwole GREGORY ${ }^{\circledR}$, Aigbedion ISAAC ${ }^{5}$
}

\author{
1Department of Applied Geophysics, Federal University of Technology, Akure, Nigeria \\ 2Department of Remote Sensing and GIS, Federal University of Technology Akure, Ondo State, Nigeria \\ 3Department of Geology, University of Calabar, Cross River State, Nigeria \\ 4Department of Physics, Ekiti State University, Ado-Ekiti, Nigeria \\ 5Department of Physics, Ambrose Alli University, Ekpoma, Nigeria
}

\author{
Keywords \\ Coefficient anisotropy \\ Longitudinal conductance \\ Transverse resistance \\ Rock types \\ Groundwater yield
}

\begin{abstract}
This study investigates the relationship among the various types of rock within the basement complex region and their possible yield in term of groundwater productivity. Four different rock types were considered at various locations in Akure metropolis. Electrical resistivity method was adopted using horizontal profiling utilizing Wenner array as well as Vertical Electrical Sounding (VES) technique using Schlumberger configuration. The horizontal profiling technique was used to determine areas characterized by structural features associated with weak zones that may be diagnostics of cracks, joints, fractures or highly weathered geologic material, while VES was used as a follow up to identified weak zones as a confirmatory test as well as delineation of layer stratification and geologic materials associated with layer parameters that maybe applicable for groundwater occurrence. The results derived from geoelectric parameters were used to determine the second order parameters (Dar-Zarrouk) for groundwater productivity modeling. The finding reflects the various yield capacity of the different rock types that were considered for this study and without prejudice to fracture/thick weathered basement.
\end{abstract}

\section{INTRODUCTION}

The problem of public water supply especially for sustainable industrial and domestic water supply has become a matter of major concern to all (Ozegin et al., 2019). This is against the background of mass neglect of public utilities by successive government since the early 1980 's, as result of corruption and lack of sustainable vision, which has prompted private efforts directed at water sustainability in form of boreholes (Ilugbo et al., 2019). However, due to rapid population growth and human development, the land use for building and industrial development is on the increase. This has becomes a major challenge within the basement complex region especially where the areas characterized by thick overburden has been subjected to other applications rather than groundwater development, thereby exposing the populate to the development, exploration and exploitation of groundwater by a way of harnessing water from structural features associated with crack, fault, fractures or highly weathered materials with little or no reasonable overburden thickness (Olorunfemi et al., 1991; Ilugbo and Adebiyi, 2017; Babatunde et al., 2018). Delineation of zones of major anomaly/weak zones characterizing of high water bearing zones for sustainable water development in a typical complex crystalline basement rock terrain such as that of Akure and its environment southwestern Nigeria,

\footnotetext{
* Corresponding Author
}

Cite this article

(mbawallah@futa.edu.ng) ORCID ID 0000-0002-7862-613X

(Kanadiat@futa.edu.ng) ORCID ID 0000-0002-2261-4543

(aakinlalu@futa.edu.ng) ORCID ID 0000-0002-6165-760X

*(bussytex4peace44@gmail.com) ORCID ID 0000-0002-1001-4815

(fakinluyi@futa.edu.ng) ORCID ID 0000-0003-4278-4926

(oobenjami@unical.edu.ng) ORCID ID 0000-0001-9196-3109

(akinkin02@yahoo.com) ORCID ID 0000-0003-4372-276X

(dromosuyi@yahoo.com) ORCID ID 0000-0002-9798-8574

(lsaacaigbedion@yahoo.com) ORCID ID 0000-0002-0969-3451

Adesola, B , Abdul-nafiu, A , Adewale, A, Olubusola S I , Omowonuola, A , Omang, B Akinola, O , Gregory, O , Isaac, A . (2021). Groundwater Sustainability and the Divergence of Rock Types in a Typical Crystalline Basement Complex Region, Southwestern Nigeria . Turkish Journal of Geosciences , 2 (1) , 1-11 . DOI: 10.48053 /turkgeo.777217 
requires a strategic approach that involve more than one geophysical techniques for random sampling (Isogun and Adepelumi, 2014; Ozegin et al., 2019). This is due to the highly localized nature of the water bearing formation/weak zones that may not be identified nor delineated by random sampling techniques using Vertical Electrical Sounding (VES). Identification of these highly localized zones of interest is very essential for the successful groundwater exploration and development (Olubusola et al., 2018). This is more so, that previous efforts at relying on just one technique in groundwater investigation (VES) has often been met by failures of poor results. This is as a result of the complex nature of the various rock types associated with the basement rock types in the region vis-à-vis their varying degree of fracturing, faulting and weathering that require delineation of viable weak zones within a particular locality, using other geophysical techniques before relying on VES for further investigation. As a result of non-availability of electromagnetic, magnetic, gravity and seismic refraction equipments for necessary reconnaissance survey in delineating structures for groundwater exploration and development (Bawallah et al., 2018). Lateral resistivity profiling has been deployed as a viable tool in delineating and mapping geologic structures within a particular location for groundwater exploration in a crystalline basement complex. This calls for ingenuity on the part of the geophysicist to deploy all this professional experience at challenging nature and getting the best in an attempt at minimizing the problem of sustainable water supply. Therefore, this study has been directed at studying different rock types, with the prospect of finding water in a basement complex environment with little or no reasonable overburden thickness in terms of geology of the environment, as was the case in this study location within the basement complex region of Akure and its environs with a view to determining its groundwater prospect, sustainability and possible yields.

\section{METHOD}

\subsection{Site Description and Geology of the Study Area}

The study area falls within Akure metropolis, Ondo State, southwestern Nigeria. It lies between latitude $798000 \mathrm{~N}$ to $810000 \mathrm{~N}$ and longitude $734700 \mathrm{E}$ to $746200 \mathrm{E}$ (Figure 1). It is well accessible through several road networks within and around the study area. The study area can be described as moderately undulating and the drainage pattern is dendritic. The climate of the area consists of two seasons; dry season (November to March) and wet season (April to October) seasons. The mean annual rainfall ranges between 1000 and $1500 \mathrm{~mm}$. The mean annual temperature distribution is $27^{\circ} \mathrm{C}$ (Iloeje, 1981). The study area is underlain by rocks of the precambrian basement complex of southwestern Nigeria (Rahaman, 1989). The geological mapping and other related studies of the area around the Akure metropolis have been carried out by several workers amongst who are (Olarewaju, 1988; Owoyemi, 1996; Odeyemi et al., 1999; Slomczyńska and Slomczyński 2004; Aluko, 2008; Adebiyi et al., 2018). The area around the Akure metropolis is underlain by eight petrological units of the basement complex of southwestern Nigeria identified by (Rahaman, 1988) and also described by (Olarewaju, 1988; Rahaman, 1988; Aluko, 2008). These are the Migmatite-Gneiss, Quartzite, Charnockitic, biotite gneiss, migmatite gneiss, pelti schist, granite gneiss and porphyritic granite (Figure 2).

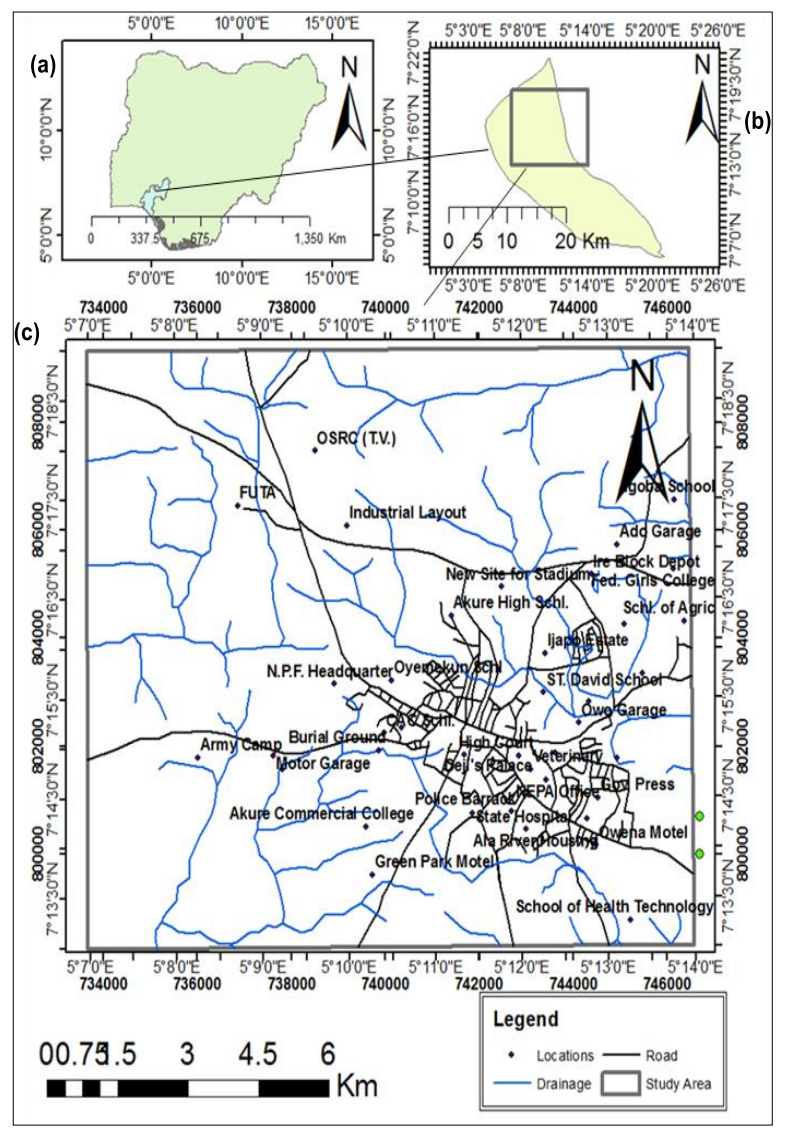

Figure 1. (a) Map of Nigeria and Ondo state showing Akure metropolis, (b) Map of Akure metropolis showing the location area (c) Location map showing the study area 


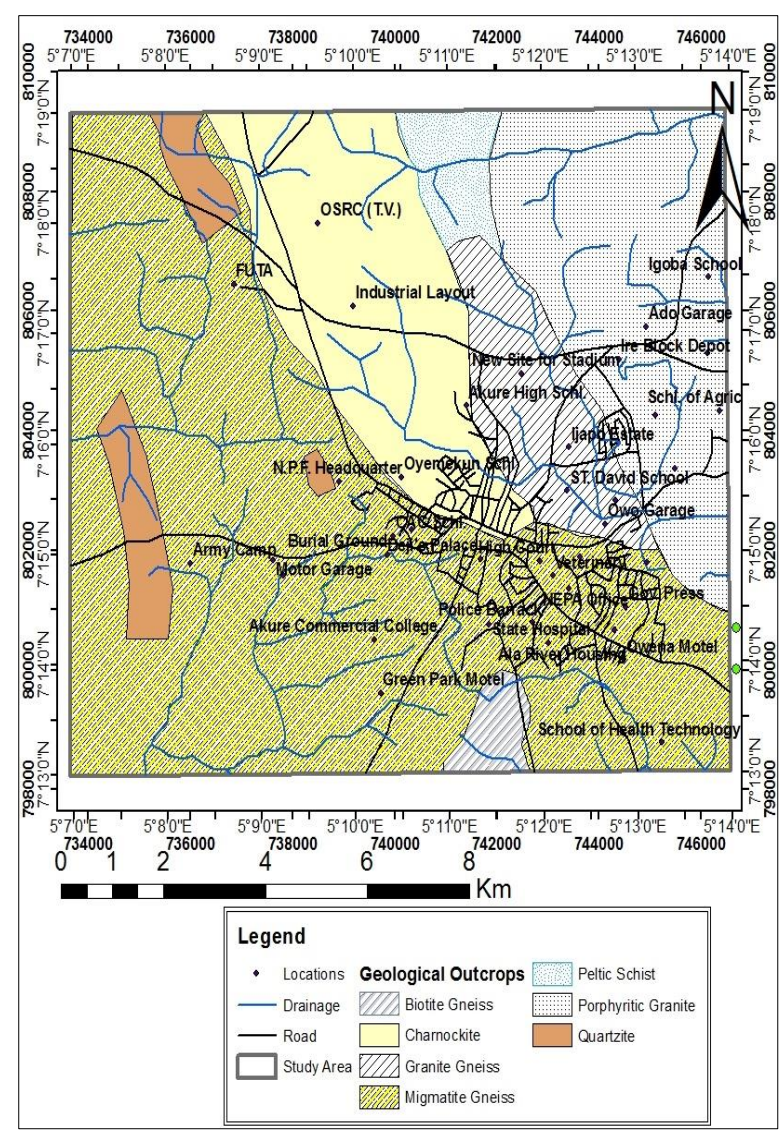

Figure 2. Geological map of the study area

\subsection{Research Methodology}

Nine locations were used for this research in Akure, Ondo State, southwestern Nigeria, with traverses established in an approximate E-W direction with length variation from $50 \mathrm{~m}$ to $200 \mathrm{~m}$ depending on available space in each of the location (Figure 3). The electrical resistivity method utilized the VES and the horizontal profiling techniques. The horizontal profiling utilizing Wenner electrode configuration of station separations and electrode spacing of $20 \mathrm{~m}$ with electrode movement of $5 \mathrm{~m}$ were used for the traverses. Resistivity values were obtained by taking readings using the omega resistivity meter. The horizontal profiling data were plotted on excel work sheet to identified the zones of contrast/anomaly. VES were carried out on points of resistivity contrast/major anomaly irrespective of weather the resistivity at any specific location is generally low or high. The VES data were presented as sounding curves, which are plots of apparent resistivity values against electrode separation $(\mathrm{AB} / 2)$ on bilogarithmic paper resulting in a VES curve. The VES curve showed the change of resistivity with depth, since the effective penetration increases with increasing electrode spacing. The interpretation of the VES curve is both qualitative and quantitative. The qualitative interpretation involved visual inspection of the sounding curves while the quantitative interpretation utilized partial curve matching technique using 2-layer master curve which was later refined by a computer iteration technique resist version (Vander, 2004) that is based upon an algorithm of (Ghosh, 1971). The quantitatively interpreted sounding curves gave results as geoelectric parameters (that is, layer resistivity and layer thickness). The Dar-Zarrouk parameters are obtained from the first order parameters (geoelectric parameters) which are total longitudinal unit conductance $(S)$, total transverse unit resistance $(\mathrm{T})$ and coefficient of anisotropy $(\lambda)$ using below mathematical expressions. The product of total transverse resistance and coefficient of anisotropy was used to determine the groundwater yield for each outcrop.

$S=\sum_{i=1}^{N} \frac{h_{i}}{\rho_{i}} \quad(\Omega-1$ or Siemens $)$

and

$T=\sum_{i=1}^{N} \rho_{i} h_{i} \quad\left(\Omega m^{2}\right)$

When a number of layers with thicknesses of $\mathrm{h} 1$, $\mathrm{h} 2, \mathrm{~h} 3$, transverse resistances of T1, T2, T3, ....., and conductance of S1, S2, S3, respectively, are involved in a geoelectrical section, their total longitudinal conductance $(\mathrm{S})$ or total transverse resistance $(\mathrm{T})$ may have to be considered (Sabnavis and Patangay, 1998) and are given by:

$$
S=S_{1}+S_{2}+S_{3}+\ldots \ldots . . \text { Where } S_{1}=\frac{h_{1}}{\rho_{1}}
$$

and

$T=T_{1}+T_{2}+T_{3}+\ldots$. Where $T_{1}=h_{1} \rho_{1}$

If the total thickness of the layers in the geoelectrical section considered is $\mathrm{H}$, then the average longitudinal resistivity $\rho t$ is given by:

$p_{l}=\sum i=1 \frac{h i}{S i}$

and the average transverse resistance $\rho_{t}$ is given by:

$\rho_{t}=\sum i=1 \frac{T i}{h i}$

$\rho t$ is always greater than $\rho l$. Therefore, the entire section will thus be always anisotropic (Singhal and Niwas 1981) with regard to electrical resistivity. The coefficient of electrical anisotropy is defined as;

$\lambda=\sqrt{\frac{\rho t}{\rho l}}$ 
Also the groundwater yield, $\mathrm{Y}$, is a function of the volume of the accumulated groundwater and the permeability of an aquifer. This is influenced, controlled and dependent on the product of coefficient of anisotropy $(\lambda)$ and total transverse resistance (T) (Bawallah et al., 2018; Olubusola et al., 2018). The relationship is shown as:

$Y=\lambda x T$

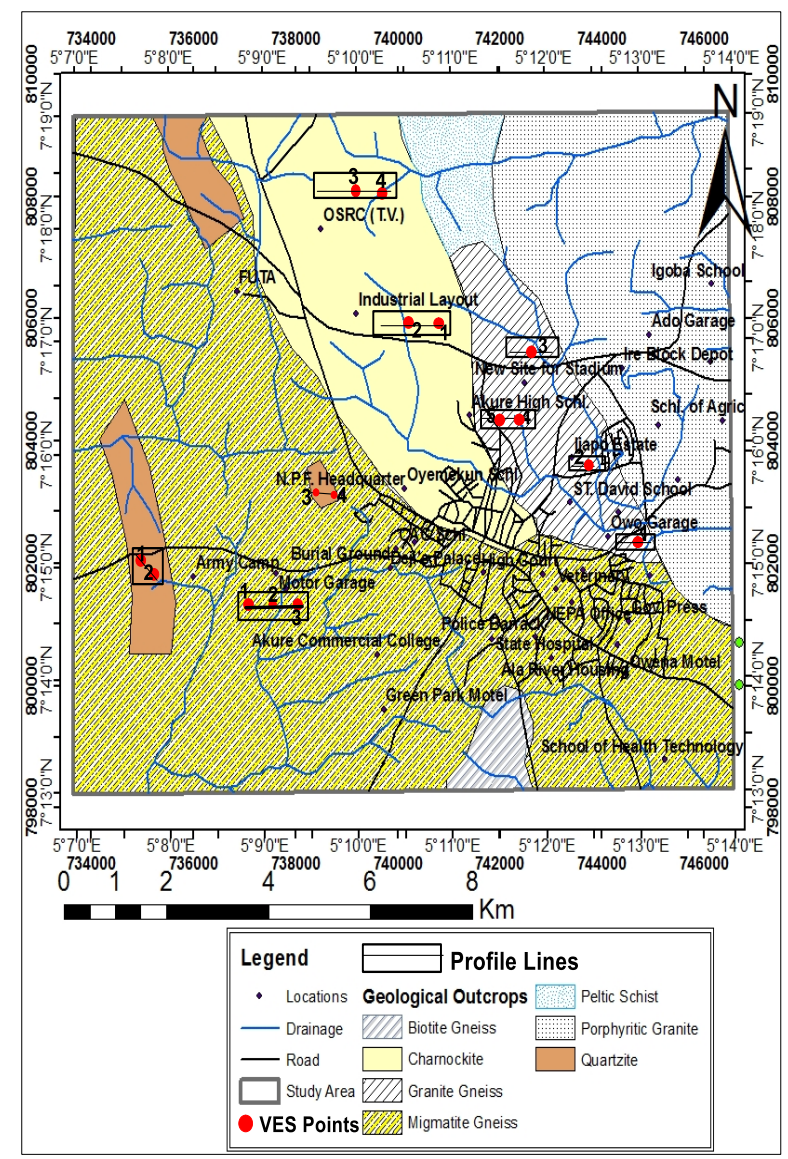

Figure 3. Data acquisitions map of the study area

\section{RESULTS and DISCUSSION}

These approaches were deployed with intention to pin down the zones of weakness that could be identified as characteristics of fracture, joint, cracks or highly weathered basement complex materials. This is against the background that all the areas of study investigated for the purpose of this research are characterized majorly by shallow overburden and many a time with very little or no overburden material with exposed fresh basement rock materials doting or been noticed within the surrounding of the study location. Therefore, the challenge here is to locate groundwater not from thick overburden but within the domain of fracture, fault or highly weathered crystalline basement rock material. Hence, the vertical electrical soundings carried out were done as follow up to identified weak zones capable of generating groundwater. However, a control measure was also adopted by sounding points that were not identified as weak zones, randomly, as a control for a better understanding of the various crystalline formation to test the effectiveness of the two techniques that were adopted for this study, hence the tables and the subsequent plots are discussed as follow.

\subsection{Migmatite Gneiss Rock}

Figure 4 showed the outcome of horizontal profiling on migmatite gneiss outcrops. The points of resistivity contrasts diagnostic of zones of geological weakness were observed at $10 \mathrm{~m}, 40 \mathrm{~m}$ and $80 \mathrm{~m}$. These points were further investigated using VES to be able to characterize these points in terms of lithological settings/layers characterization and overburden thickness. From table 1, three VES were carried out at this location. Two of the VES were carry out based on result from Wenner profiling, while the third was carried out randomly as a control to established the effectiveness of Wenner profiling technique in identifying proactive weak zone using gradient approach in a difficult basement complex environment coupled with little or no overburden materials from the result obtained, the most promising point on the profile was located at distance of $15 \mathrm{~m}$. The results obtained from the VES was used to determined the second order DarZarrouk parameters, the result from the VES1 has total longitudinal conductance of $0.103092 \Omega^{-1}$, total transverse resistance value of $65787.5 \Omega \mathrm{m}-2$ and coefficient of anisotropy $(\lambda)$ of 1.647082 from which the groundwater yield was determined from the product of total transverse resistance and coefficient of anisotropy ( $\mathrm{T}$ and $\lambda$ ) to be $108,357.4$ which is a reflection of the groundwater yield capacity of that point. A similar approach was adopted for the second and third VES that were randomly investigated to identify fairly weak zone from Wenner profiling. The findings reveal that the groundwater yield for these points was obtained to be 4401.119 and 26512.6 yield capacity for VES2 and VES3.

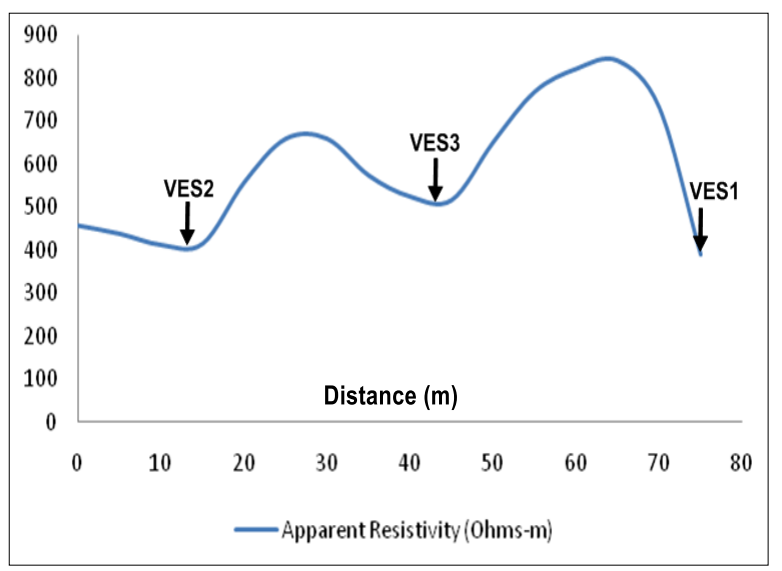

Figure 4. Horizontal profiling along ondo road 
Table 1. Dar-Zarrouk parameters and groundwater yield of migmatite gneiss

\begin{tabular}{|l|l|l|l|l|l|}
\hline $\begin{array}{l}\text { Migmatite } \\
\text { Gneiss }\end{array}$ & $\begin{array}{l}\text { Total Longitudinal } \\
\text { Conductance }(\mathrm{S})\left(\Omega^{-1}\right)\end{array}$ & $\begin{array}{l}\text { Total Traverse } \\
\text { Resistance }(\mathrm{T}) \\
\left(\Omega \mathrm{m}^{2}\right)\end{array}$ & $\begin{array}{l}\text { Coefficient of } \\
\text { Anisotropy }(\lambda)\end{array}$ & $\begin{array}{l}\text { Groundwater } \\
\text { Yield }\left(\mathrm{T}^{*} \lambda\right)\end{array}$ & Remarks \\
\hline VES1 & 0.103092 & 65787.5 & 1.647082 & 108357.4 & $\begin{array}{l}\text { Thin weathered } \\
\text { layer/Fracture extent }\end{array}$ \\
\hline VES2 & 0.063207 & 3553.4 & 1.238566 & 4401.119 & $\begin{array}{l}\text { Thin weathered } \\
\text { layer/Fracture extent }\end{array}$ \\
\hline VES3 & 0.082704 & 24658.1 & 1.075208 & 26512.6 & $\begin{array}{l}\text { Thick weathered } \\
\text { layer/Fracture extent }\end{array}$ \\
\hline
\end{tabular}

\subsection{Charnockite Rock}

Figure 5 was obtained from measurement carried out across charnockite dominated environment along industrial layout. The profile exhibited generally how resistivity contrasts of 120 $\Omega \mathrm{m}$. Therefore, considering the inherent nature of charnockite which weathered into clay, and the intrinsic properties of clay in terms of water yield capacity, zone of high resistivity contrasts were considered for VES to be able to characterize the area in terms of layer formations/stratification and bedrock configuration for groundwater yield consideration. Another study was carried out on charnockite dominated environment along Orita Obelle area of Akure (Figure 6). The results show low resistivity throughout the profile reflecting on the clayey nature of the formation emanating from the weathering product of charnockite except between zero to $10 \mathrm{~m}$ where the resistivity value is relatively high. Therefore, for the purpose of groundwater yield, the zone of moderately high resistivity contrasts and moderately low resistivity contrasts were considered for further investigation using VES. The information obtained from this location indicated that; for the major weak zone (VES1), the yield parameter obtained from Dar-Zarouk parameters where total longitudinal conductance has a value of $0.238845 \Omega^{-1}$ and total transverse resistance of $13488.9 \Omega \mathrm{m}^{-2}$ with coefficient of anisotropy of 1.42257 . The groundwater yield capacity was determined from the product of total transverse resistance and coefficient of anisotropy ( $\mathrm{T}$ and $\Lambda$ ) as 19188.9 yield capacity. A similar process was adopted for VES2, VES3 and VES4 with their yield rating obtained as 16376.38, 14118.55 and 1261.768 yield capacity (Table 2), all of which were considered as controlled except for VES1 which was recommended for drilling base on its yield parameter rating.

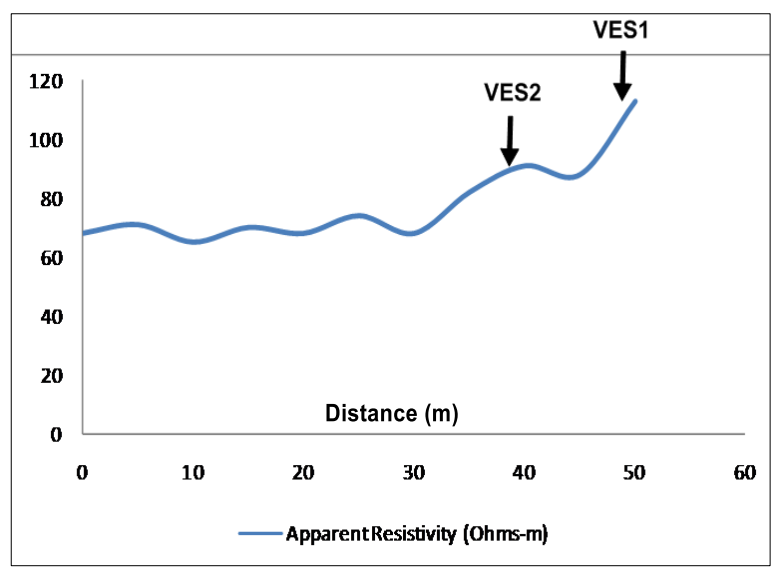

Figure 5. Horizontal profiling along industrial layout

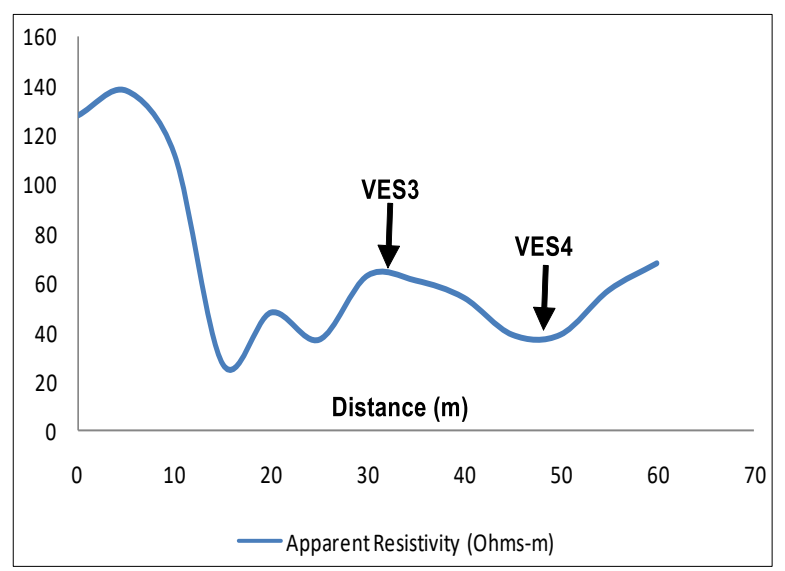

Figure 6. Horizontal profiling along orita obele

Table 2. Dar-Zarrouk parameters and groundwater yield of charnockite

\begin{tabular}{|l|l|l|l|l|l|}
\hline Charnockite & $\begin{array}{l}\text { Total Longitudinal } \\
\text { Conductance }(S)\left(\Omega^{-1}\right)\end{array}$ & $\begin{array}{l}\text { Total Traverse } \\
\text { Resistance }(\mathrm{T})\left(\Omega \mathrm{m}^{2}\right)\end{array}$ & $\begin{array}{l}\text { Coefficient of } \\
\text { Anisotropy }(\lambda)\end{array}$ & $\begin{array}{l}\text { Groundwater } \\
\text { Yield }\left(\mathrm{T}^{*} \lambda\right)\end{array}$ & Remarks \\
\hline VES1 & 0.238845 & 13488.9 & 1.42257 & 19188.9 & $\begin{array}{l}\text { Thick weathered } \\
\text { layer/Fracture extent }\end{array}$ \\
\hline VES2 & 0.140923 & 6886.5 & 2.37804 & 16376.38 & $\begin{array}{l}\text { Fairly thick weathered } \\
\text { layer/Fracture extent }\end{array}$ \\
\hline VES3 & 0.468766 & 7356.8 & 1.919116 & 14118.55 & $\begin{array}{l}\text { Fairly thick weathered } \\
\text { layer/Fracture extent }\end{array}$ \\
\hline VES4 & 0.68402 & 663.4 & 1.901972 & 1261.768 & $\begin{array}{l}\text { Very thin weathered } \\
\text { layer/Fracture extent }\end{array}$ \\
\hline
\end{tabular}




\subsection{Granite Gneiss Rock}

Figure 7 showed that the study area was characterized by high resistivity with lowest being $240 \Omega \mathrm{m}$ at the beginning of the measurement point, and continue to increase even beyond $400 \Omega \mathrm{m}$ towards the end of the profile indicating the nature and it geological settings and structural disposition from the beginning to the end of the profile. A follow up investigation was carried out at the point considered as the weak zone (lowest resistivity contrast) for further consideration using VES for the purpose of groundwater potential yield. Another investigation was carried out at Ijapo area of Akure metropolis across the same rock types (Granite Gneiss) with rock exposure and low lying outcrops (Figure 8). The profile covered a distance of $50 \mathrm{~m}$ while the weak zone delineated resulting from resistivity contrast was located at $10 \mathrm{~m}$. Figure 9 was carried out on the same outcrop along Araromi area of Akure, following the same principle and approach which covered a distance of $50 \mathrm{~m}$. On this location, the zone of major resistivity contrasts anomaly was identified at $30 \mathrm{~m}$ upon which further investigation was carried out in order to determine its hydrogeological parameters/geological setting using VES. Furthermore, this research effort was extended to another location along Akure high school area of Akure (Figure 10), where measurement obtained from this area shows two anomalous zones (zones of weakness). These zones were further investigated for lithological setting, geoelectric parameters and bedrock depositions to determine the groundwater potential and yield. The VES was carried out on the identify major weak zones obtained from horizontal profiling to delineate major structural feature, that could be diagnostic of fracture, fault or highly weathered material that could accumulate groundwater exploration and development. In all the five (5) point for the purpose of control and better understanding of the geology and effective correlation of events. The result obtained using the second order parameters (Dar-Zarrouk), indicated a groundwater yield maximum of 8125.562, 11472.65, 15748.28, 5325.984 and 4174.991 for VES1, VES2, VES3, VES4 and VES5 (Table 3). Whereas, all these yield parameters are not reasonable enough to allow groundwater developing, thereby reflecting the importance of narrowing down point of interest with horizontal profiling, as none of these investigated VES points can support borehole and groundwater exploration and development in term of water yield parameters. Justifying the importance's of lateral resistivity profiling technique with VES as a major tool in identifying weak zones in a typical crystalline basement complex region.

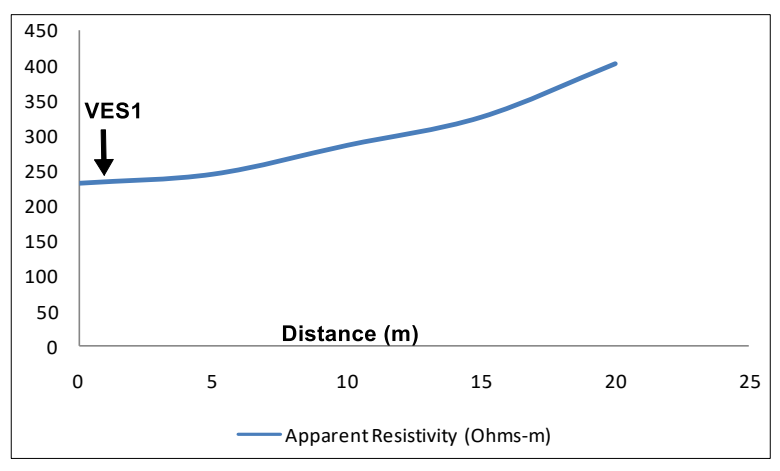

Figure 7. Horizontal profiling along owo garage

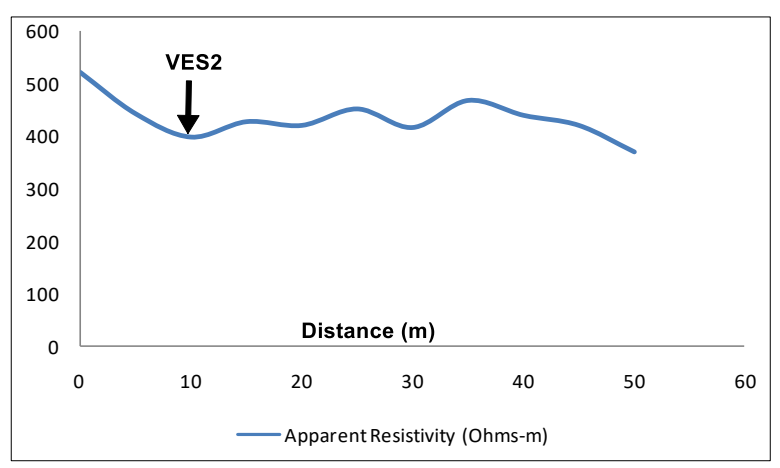

Figure 8. Horizontal profiling along Ijapo estate

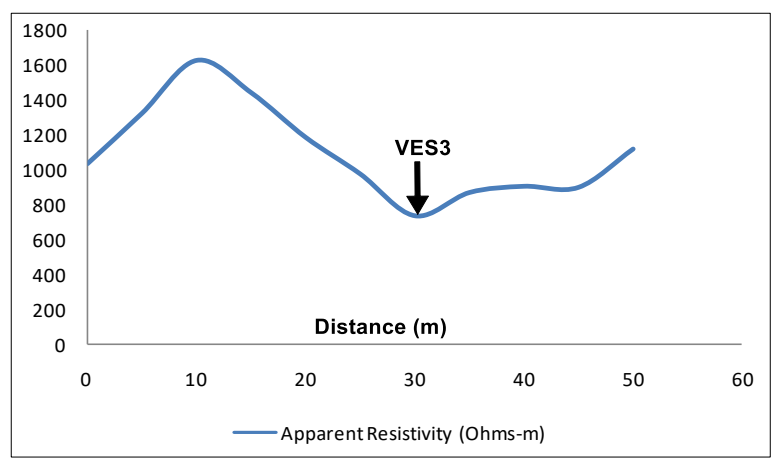

Figure 9. Horizontal profiling along Araromi

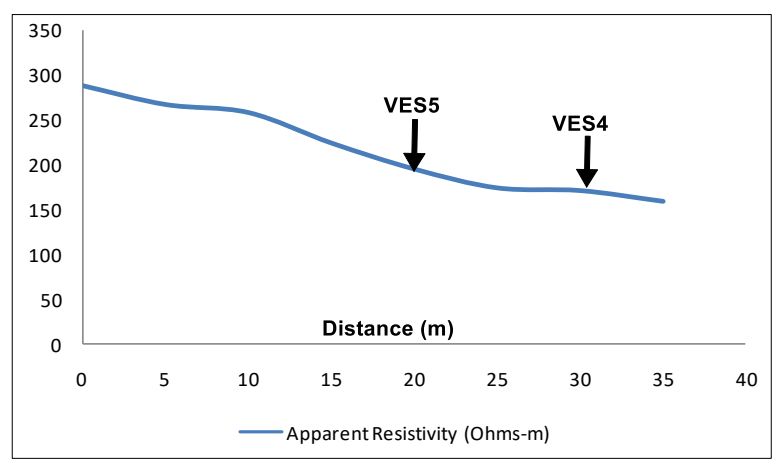

Figure 10. Horizontal profiling along Akure high school 
Table 3. Dar-Zarrouk parameters and groundwater yield of granite gneiss

\begin{tabular}{|l|l|l|l|l|l|}
\hline $\begin{array}{l}\text { Granite } \\
\text { Gneiss }\end{array}$ & $\begin{array}{l}\text { Total Longitudinal } \\
\text { Conductance }(\mathrm{S})\left(\Omega^{-1}\right)\end{array}$ & $\begin{array}{l}\text { Total Traverse } \\
\text { Resistance }(\mathrm{T})\left(\Omega \mathrm{m}^{2}\right)\end{array}$ & $\begin{array}{l}\text { Coefficient of } \\
\text { Anisotropy }(\lambda)\end{array}$ & $\begin{array}{l}\text { Groundwater } \\
\text { Yield }\left(\mathrm{T}^{*} \lambda\right)\end{array}$ & Remarks \\
\hline VES1 & 0.142428 & 5872.2 & 1.383734 & 8125.562 & $\begin{array}{l}\text { Very thin weathered } \\
\text { layer }\end{array}$ \\
\hline VES2 & 0.064273 & 8461.6 & 1.355848 & 11472.65 & $\begin{array}{l}\text { fairly thin weathered } \\
\text { layer/Fracture extent }\end{array}$ \\
\hline VES3 & 0.097934 & 13450.9 & 1.170797 & 15748.28 & $\begin{array}{l}\text { fairly thin weathered } \\
\text { layer/Fracture extent }\end{array}$ \\
\hline VES4 & 0.130881 & 4528.5 & 1.176103 & 5325.984 & $\begin{array}{l}\text { very thin weathered } \\
\text { layer/Fracture extent }\end{array}$ \\
\hline VES5 & 0.042053 & 3687.8 & 1.132109 & 4174.991 & $\begin{array}{l}\text { very thin weathered } \\
\text { layer/Fracture extent }\end{array}$ \\
\hline
\end{tabular}

\subsection{Quartzite Rock}

Figure 11 showed the outcome of the horizontal profiling along quartzite outcrops and two major zones of weakness were observed at 30 and $35 \mathrm{~m}$ which area diagnostic of fracture/fault, cracks/joints or high weathered geologic material which is relevant to groundwater potential yield evaluation. The results obtained at lafe environment along former police headquarter within the Akure metropolis (Figure 12). A similar procedure was carried out to obtained relevant information

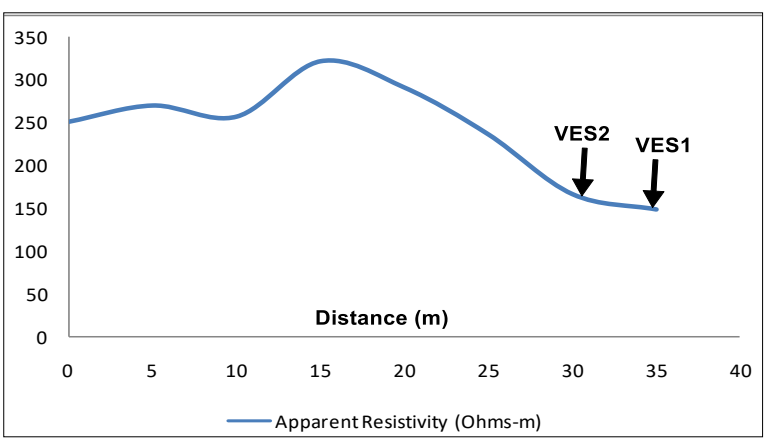

Figure 11. Horizontal profiling along army barrack necessary to determine the hydrogeological settings and groundwater yield parameters. The zones of weakness were further considered using VES. The location was characterized as quartzite ridge with exposed outcrops of quartzite dotting the entire study area. The groundwater yield parameters obtained were; 5064.894, 1160.35, 17559.38 and 27048.61 for VES1, VES2, VES3 and VES4 (Table 4). The result obtained from lateral resistivity profiling correlated effectively with VES in terms of weak zones.

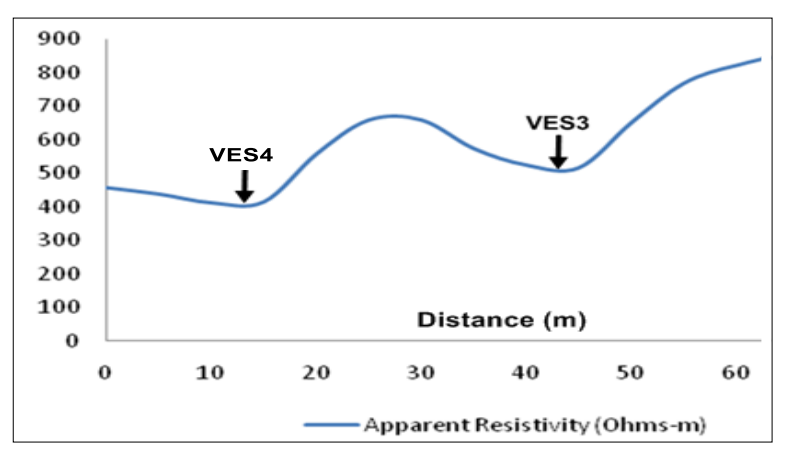

Figure 12. Horizontal profiling along NPF headquarter

Table 4. Dar-Zarrouk parameters and groundwater yield of quartzite

\begin{tabular}{|l|l|l|l|l|l|}
\hline Quarzite & $\begin{array}{l}\text { Total Longitudinal } \\
\text { Conductance }(\mathrm{S})\left(\Omega^{-1}\right)\end{array}$ & $\begin{array}{l}\text { Total Traverse } \\
\text { Resistance }(\mathrm{T})\left(\Omega \mathrm{m}^{2}\right)\end{array}$ & $\begin{array}{l}\text { Coefficient of } \\
\text { Anisotropy }(\lambda)\end{array}$ & $\begin{array}{l}\text { Groundwater } \\
\text { Yield }\left(\mathrm{T}^{*} \lambda\right)\end{array}$ & Remarks \\
\hline VES1 & 0.285939 & 4245 & 1.193143 & 5064.894 & $\begin{array}{l}\text { very thin weathered } \\
\text { layer/Fracture extent }\end{array}$ \\
\hline VES2 & 0.027263 & 10901.6 & 1.064188 & 11601.35 & $\begin{array}{l}\text { fairly thin weathered } \\
\text { layer/Fracture extent }\end{array}$ \\
\hline VES3 & 0.008572 & 16915.2 & 1.038083 & 17559.38 & $\begin{array}{l}\text { moderately thick } \\
\text { weathered } \\
\text { layer/Fracture extent }\end{array}$ \\
\hline VES4 & 0.003182 & 26508 & 1.020394 & 27048.61 & $\begin{array}{l}\text { thick weathered } \\
\text { layer/Fracture extent }\end{array}$ \\
\hline
\end{tabular}

\subsection{Correlation of Results}

\subsubsection{Total longitudinal conductance}

For better understanding of the yield parameters of the different rock types (Granite gneiss, Migmatite gneiss, Quartzite and charnockite) that were found in the investigated locations. The results obtained were correlated in terms of their various total longitudinal conductance $\left(\Omega^{-1}\right)$ (Figure 13). Colour separation was used to indicate the performance of each of the outcrops which are very important indicators in terms of groundwater yield. This graph shows that the lower the total longitudinal conductance parameters of a crystalline basement rock, the greater are the prospect 
groundwater yield of the outcrops and the higher the total longitudinal conductance parameters of the crystalline basement rocks, the lower the prospect groundwater yield of such rocks.

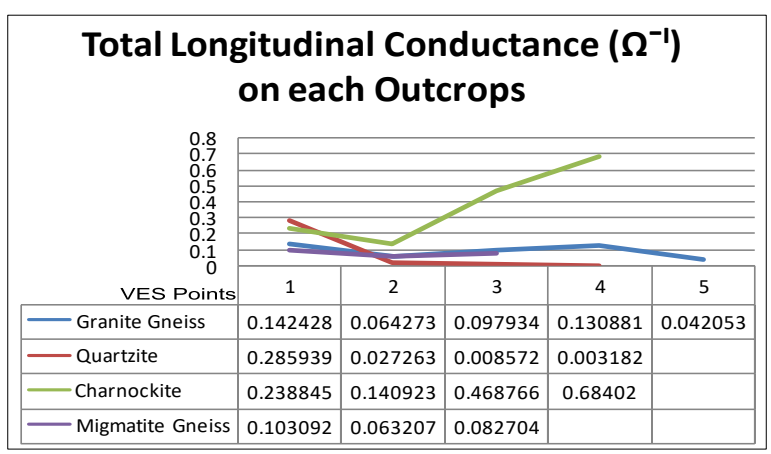

Figure 13. Correlation of total longitudinal conductance across the various rock types within the study area

\subsubsection{Total transverse resistance}

Figure 14 displays the total transverse resistance of the various outcrops within the study area. It can be further inferred that the higher the total transverse resistance of any crystalline basement rock, the greater is it capacity to yield groundwater and it has inverse relationship with total longitudinal conductance.

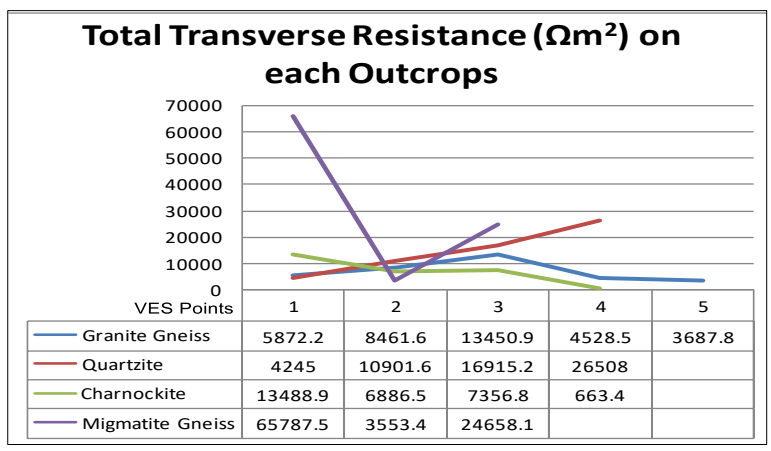

Figure 14. Correlation of total transverse resistance across the various rock types within the study area

\subsubsection{Ceofficient of anisotropy $(\lambda)$}

Compact rock at shallow depth increases the coefficient of the anisotropy (Keller and Frischknecht, 1966). Hence, these areas can be associated with low porosity and permeability. The areas with 1.0 and less than 1.5 anisotropy values (high porosity and permeability) are considered as high groundwater potential zones (Rao et al., 2003). The coefficient of anisotropy $(\lambda)$ has been shown to have the same functional form as permeability anisotropy. Thus, a higher coefficient of anisotropy $(\lambda)$ implies higher permeability anisotropy. Figure 15 illustrates the coefficient of anisotropy of each outcrops, it can be inferred that the high the coefficient of anisotropy parameters of any crystalline basement rock, the greater is the prospect for groundwater and also the lower for coefficient of anisotropy, the lower for groundwater prospect without prejudice overburden or weathered layer thickness. The results inferred from coefficient of anisotropy and total longitudinal conductance of each outcrops have a direct relationship.

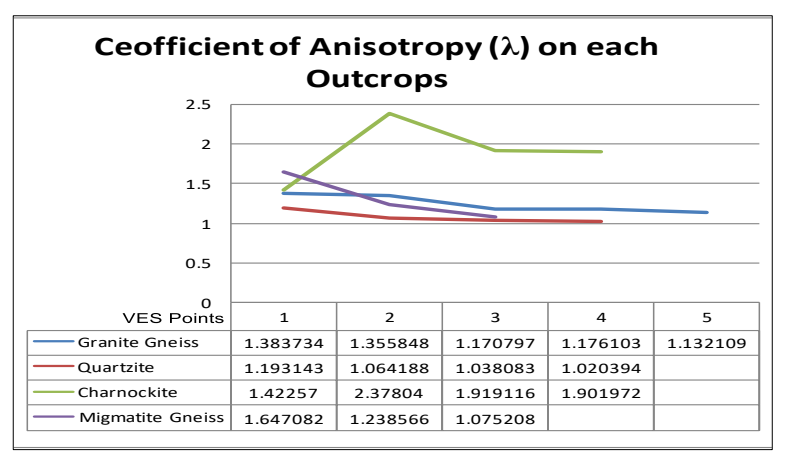

Figure 15. Correlation of coefficient of anisotropy across the various rock types within the study area

\subsubsection{Groundwater yield $\left(T^{*} \lambda\right)$}

The groundwater yield of each outcrop was obtained from the product of total transverse resistance (T) and coefficient of anisotropy $(\lambda)$ (Bawallah et al., 2018) which was able to establish the productivity of crystalline basement complex in term of its yield parameters (Figure 16). It further demonstrated the effective correlation of all the approach that was used in the characterization of groundwater yield capacity of crystalline basement rock within the study area. The highest yield results from the various rock types were obtained as 15748.28, 26512.6, 19188.9 and 27048.61 for granite gneiss, migmatite gneiss, charnockite and quartzite. From this analysis it can be inferred that for a typical crystalline basement complex to have better prospect for groundwater, it must base on the various groundwater yield classification (Table 5).

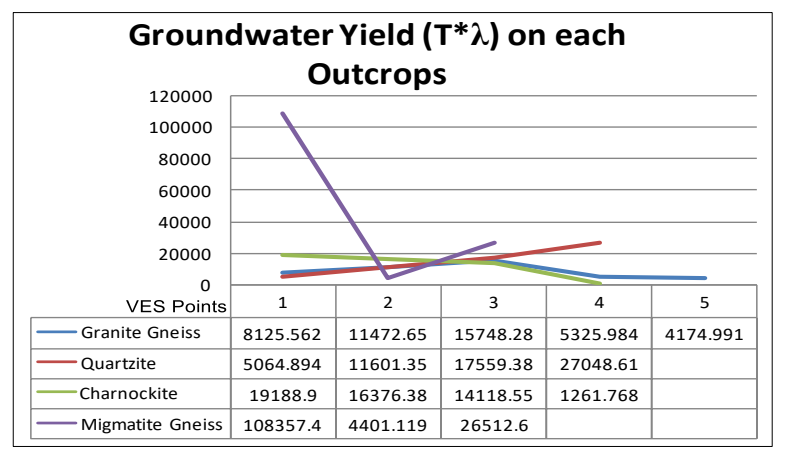

Figure 16. Groundwater yield across the various rock types within the study area 
Table 5. Groundwater yield classifications

\begin{tabular}{|c|c|c|}
\hline Rock Types & Groundwater Yield Capacity Value & Classification \\
\hline Granite Gneiss & Below 8000 & No prospect \\
& $8000-11000$ & Low yield \\
& $11000-15000$ & Moderate/Medium Yield \\
& 15000 and above & High Yield \\
\hline Quartzite & Below 10000 & Extremely low yield \\
& $10000-15000$ & Low yield \\
& $15000-17000$ & High yield \\
& $17000-20000$ & Very high yield \\
\hline Charnockite & 20000 and above & Very low yield \\
& Below 8000 & Low yield \\
& $12000-12000$ & Moderate yield \\
& $15000-20000$ & High yield \\
& 20000 and above & Very high yield \\
\hline Migmatite Gneiss & Below 5000 & Very low yield \\
& $5000-10000$ & Low yield \\
& $10000-12000$ & Moderate yield \\
& $12000-15000$ & High yield \\
& 15000 and above & Very high yield \\
\hline
\end{tabular}

\subsection{Validation/Pumping Test Results}

The validation for groundwater taken beyond the domain of using the parameters of precipitation, evaporation and others to determine groundwater yield, but in this study direct measurement of borehole yields was used for the evaluation and rating of groundwater prospect and yield within the study area.

\section{Loction 1: Charnockite Environment}

Pumping machine capacity = one horse power Overhead tank/reservoir capacity $=1000$ litres Distance travel by water from borehole to reservoir $=5$ meters

Time taken to fill reservoir $=12$ minutes $=12 \times 60=$ $720 \mathrm{sec}$

Yield $=\frac{1000(\text { litres })}{720(\mathrm{sec})} \times$ pumping machine capacity $\mathrm{x}$ distance travel

Yield $=\frac{1000}{720} \times 1 \times 5=6.94$ litres per sec

\section{Loction 2: Quartzite Environment}

Pumping machine capacity = one horse power Overhead tank/reservoir capacity $=1500$ litres Distance travel by water from borehole to reservoir $=30$ meters

Time taken to fill reservoir $=45 \mathrm{~min}=45 \times 60=2700$ sec

Yield $=\frac{1500(\text { litres })}{2700(\mathrm{sec})} \times$ pumping machine capacity $\mathrm{x}$ distance travel

Yield $=\frac{1500}{2700} \times 1 \times 30=16.66$ litres per sec

\section{Loction 3: Migmatite Gneiss environment}

Pumping machine capacity = one horse power Overhead tank/reservoir capacity $=1500$ litres
Distance travel by water from borehole to reservoir $=30$ meters

Time taken to fill reservoir $=1 \mathrm{hr}=60 \times 60=3600$ sec

Yield $=\frac{1500(\text { litres })}{3600(\mathrm{sec})} \times$ pumping machine capacity $\mathrm{x}$ distance travel

Yield $=\frac{1500}{3600} \times 1 \times 30=12.5$ litres per sec

\section{CONCLUSION}

This study has showed the significance of two techniques in groundwater search in a typical crystalline basement complex with shallow overburden without prejudice to overburden thickness and weathered layer thickness, which may have some degrees of influence on these findings. This study has been able to establish the relationship existing between nature and types of crystalline rock and their groundwater yield/productivity. The highest yield results from the various rock types were obtained as 15748.28, 26512.6, 19188.9 and 27048.61 for granite gneiss, migmatite gneiss, charnockite and quartzite respectively. It can be inferred that for a crystalline basement rocks to be productive in term of groundwater, it is expected to have various groundwater yield classifications. Therefore, it can be infer that without drilling, groundwater productivity and yield can be determined theoretically following these principles. It is of the strong opinion of the authors that it is possible to determine how prolific a borehole would be even before drilling with the adoptions of the approach in this study.

\section{DATA AVAILABILITY STATEMENT}

The authors confirm that the data supporting the findings of the study are available within the article and its supplementary materials. Authors 
have declared that no competing interests exist and the data was not use as an avenue for any litigation but for the advancement of knowledge.

\section{ACKNOWLEDGEMENT}

The authors gratefully acknowledge Prof. Aina A.O. and Oladeji J.F for their valuable contribution at improving the quality of this research work.

\section{REFERENCES}

Adebiyi, A.D., Ilugbo, S.O., Bamidele, O. E., \& Egunjobi, T. (2018). Assessment of aquifer vulnerability using multi-criteria decision analysis around akure industrial estate, Akure, southwestern Nigeria. Journal of Engineering Research and Reports, 1-13.

Aluko, A.B. (2008). Geology of Akure Area Southwestern Nigeria. Unpublished B. Tech. Thesis, Federal University of Technology, Akure, 70.

Babatunde, A.A., Olubusola, I.S., \& Emmanuel, O.F. (2018). Modeling of groundwater potential using Vertical Electrical Sounding (VES) and multi-caterial analysis at omitogun housing estate, Akure, southwestern Nigeria. Asian Journal of Advanced Research and Reports, 1-11.

Bawallah, M.A., Aina, A.O., Ilugbo, S.O., Ozegin, K.O., \& Olasunkanmi, K.N. (2018). Evaluation of groundwater yield capacity using Dar-zarrouk parameter of central Kwara State, Southwestern Nigeria. Asian Journal of Geological Research, 113.

Ghosh, D.P. (1971). The application of linear filter theory to the direct interpretation of geoelectrical resistivity sounding measurements. Geophysical prospecting, 19(2), 192-217.

Iloeje, N.P. (1981). A new geography of Nigeria (New Revised Edition). Longman Group: London, UK. 32-45.

Ilugbo, S.O., Adebiyi, A.D. (2017). Intersection of lineaments for groundwater prospectanalysis using satellite remotely sensed and aeromagnetic dataset around Ibodi, Southwestern Nigeria. International Journal of Physical Sciences, 12(23), 329-353.

Ilugbo, S.O., Edunjobi, H.O., Alabi, T.O., Ogabi, A.F., Olomo, K.O., Ojo, O.A. \& Adeleke, K.A. (2019). evaluation of groundwater level using combined electrical resistivity log with gamma (Elgg) around Ikeja, Lagos State, Southwestern Nigeria, Asian Journal of Geological Research, 1-13.
Isogun, M.A., Adepelumi, A.A. (2014). The review of seismicity of crustal Mid-Atlantic fracture zone. International Journal of Scientific and Engineering Research, 5(10), 1309-1316.

Keller, G.V., Frischknecht, F.C. (1966). Electrical methods in geophysical prospecting (pp. 179187), Pergamon Press Inc., Oxford.

Odeyemi, I.B., Asiwaju-Bello, Y.A., \& Anifowose A.Y.B. (1999). Remote sensing fracture characteristics of the Pan African granite batholiths in the Basement Complex of parts of south western Nigeria. The Journal of Technoscience, 3, 56-60.

Olarewaju, V.O. (1988). REE in charnockitic and associated granitic rocks of Ado-Ekiti-Akure, SW Nigeria. Precambrian Geology of Nigeria, Geological Survey of Nigeria Publication, Kaduna, 231-239.

Olorunfemi, M.O., Olarewaju, V.O. \& Alade, O. (1991). On the electrical anisotropy and groundwater yield in a basement complex area of SW Nigeria. Journal of African Earth Sciences, 12(3):462472.

Olubusola, I., Daniel, A., \& Oladimeji, O. (2018). Modeling of groundwater yield using GIS and electrical resistivity method in a basement complex Terrain, Southwestern Nigeria. Journal of Geography, Environment and Earth Science International, 16(1), 1-17.

Olubusola, I.S., Adebo, B.A., Oladimeji, O.K., \& Ayodele, A. (2018). Application of GIS and multicriteria decision analysis to geoelectric parameters for modeling of groundwater potential around Ilesha, Southwestern Nigeria. European Journal of Academic Essays, 5(5), 105123.

Owoyemi, F.B. (1996). A Geologic-Geophysical Investigation of rain-Induced erosional features in Akure metropolis. Unpublished M.Sc. Thesis, Federal University of Technology, Akure. 11-18.

Ozegin, K.O., Bawallah, M.A., Ilugbo, S.O., Oyedele, A.A., \& Oladeji, J.F. (2019). Effect of geodynamic activities on an existing dam: A case study of Ojirami Dam, Southern Nigeria. Journal of Geoscience and Environment Protection, 7(9), 200-213.

Rahaman, M.A. (1988). Recent advances in the study of the basement complex of Nigeria. In Oluyide PO, Mbonu WC, Ogezi AE, Egbuniwe IG, Ajibade AC, Umeji AC. (Eds.). Precambrian Geology of Nigeria. Geological Survey of Nigeria Special Publication. 11-41. 
Rahaman, M.A. (1989). Review of the basement geology of southwestern Nigeria: In Geology of Nigeria (Kogbe CA Ed.). Elizabeth Publishing. Co. Nigeria. 41-58.

Rao, P.J., Rao, B.S., Rao, M.J., \& Harikrishna, P. (2003). Geo-electrical data analysis to demarcate groundwater pockets and recharge zones in Champavathi River Basin, Vizianagaram District, Andhra Pradesh. J. Indian Geophys. Union, 7(2), 105-113.

Sabnavis, M., Patangay, N.S. (1998). Principles and applications of groundwater Geophysics, Publ. by AEG, OU, nHyderabad p 421.
Singhal, D.S., Niwas, S., (1981). Examination of quifertransmissivity from Dar Zarrouk parameters in porous media, Jour. of Hydrology, Vol.50 pp 393-399.

Słomczyńska, B., Słomczyński, T. (2004). Physicochemical and toxicological characteristics of leachates from MSW landfills. Polish Journal of Environmental Studies, 13(6), 627-637.

Vander Velpen, B.P.A. (2004). Resist Version 1.0. M.Sc. Research Project, ITC, Delft Netherland"

(C) Author(s) 2021. This work is distributed under https://creativecommons.org/licenses/by-sa/4.0/ 